\title{
Safety analysis of sea border transportation in indonesia, case study : countries between countries in sumatera (batam - singapore and batam - johor)
}

\author{
Danny Faturachman ${ }^{1, *}$ \\ ${ }^{1}$ Marine Engineering Department, Darma Persada University, Jl. Taman Malaka Selatan, Pondok \\ Kelapa, Jakarta Timur, 13450, Indonesia
}

\begin{abstract}
As a border in Sumatera Island, Batam as a bridge between Indonesia and Singapore, and also Indonesia and Malaysia. Batam located in locations strategic considering in the sea border area, crossing between in Sumatera with Singapore and Johor, Malaysia. This research is aim to know whether the ASEAN Economic Community in order to ASEAN connectivity since 2015 application has already settle or not. .Because connectivity between ASEAN countries considered an important part in the context of creating the implementation of ASEAN economic community characterized by an open market in southeast Asia, therefore sea border transportation needs to develop again. This research is case study directly to see the fact in ferry routes between Batam - Singapore and also Batam - Johor and gain the information about the ferries, terminal and also the impact for the sea border transportation of three countries between Indonesia, Singapore and Malaysia.
\end{abstract}

\section{Introduction}

The development of transportation in Indonesia, especially sea transportation has been increased nowadays. This is the impact of economic activities and social experience culture and society. In addition, Indonesian sea waters besides as a link among cities and island, also among countries. As the border in Sumatera Island, Batam as a bridge between Indonesia, Singapore and Malaysia. Geographically, Riau Islands province with the boundaries of as follows; Northern: Vietnam and Cambodia, Southern: Bangka Belitung province and Jambi province, Western: Singapore, Malaysia and Riau province, Eastern: Malaysia and West Kalimantan province. In addition, Riau Islands province having smaller islands are almost spread across the city, including of them smaller islands that situated in the region of the borders of Indonesia.

The objective of the paper in order to safety analysis of sea border transportation crossing between countries especially between Indonesia, Singapore and Malaysia will look at how the crossing of the ship passing between that three countries. There will also be seen how safety standards which refers to SOLAS especially the safety equipment have been fulfilled on the ship. There will also be seen the condition of the crossing in port of Batam (in Sekupang, one of five ferry terminal in Batam), Harbor Front in Singapore and Stulang Laut, Johor Malaysia in terms of safety would have sufficient and appropriate for passengers. As a border in Sumatera island, the city of Batam as a bridge between Indonesia, Singapore and Malaysia .For all this necessary,

\footnotetext{
*Corresponding Author: fdanny30@yahoo.com
} 
safety and security on cruise in the three countries for maritime safety affected business sustainable development especially in sea transportation activity. The method is case study with the data collection gained from the field on board between ferries on Batam - Singapore and Batam - Johor.

\section{Literature Review}

Indonesian's act no. 17 about cruise state that[6]:

- Ship safety and security is a state of the fulfillment safety requiresment and security in waters on transport, port and environment maritime;

- Ship safety is a state of vessel complient material, construction, ship engines and electricity, stability, general arrangement and equipment, a salvage supporter and radio, electronic of the ship, as evidenced by certificate post examination and testing.

\subsection{Review Batam City}

Batam City is one of municipal who are in the province of Riau Islands located at $0^{\circ} 25^{`} 9\left\|-1^{\circ} 15^{`} 00\right\|$ northern latitudes and $103^{\circ} 34^{`} 35\left\|-104^{\circ} 26^{`} 4\right\|$ east longitude. Batam City having broad territorial waters reached $1.570 \mathrm{~km}^{2}$. The land area inhabited by 988.550 peoples, so that population density in the city as many as 38.661 persons $/ \mathrm{km}^{2}$. This population is the third populous of Sumatra Island after Medan City and Padang City. Batam City consisting of so many regions, there are Batu Ampar, Belakang Padang, Bulang, Galang, Lubuk Baja, Sei Beduk, Batu Aji, Segulung, Bengkong, the city of Batam and Sekupang [3]. Batam City is located very strategic island due to located along the international shipping with the limits of the area as follows: North Singapore and Malaysia, South Lingga district, West Karimun district, East the island of Bintan and Tanjung Pinang [1].

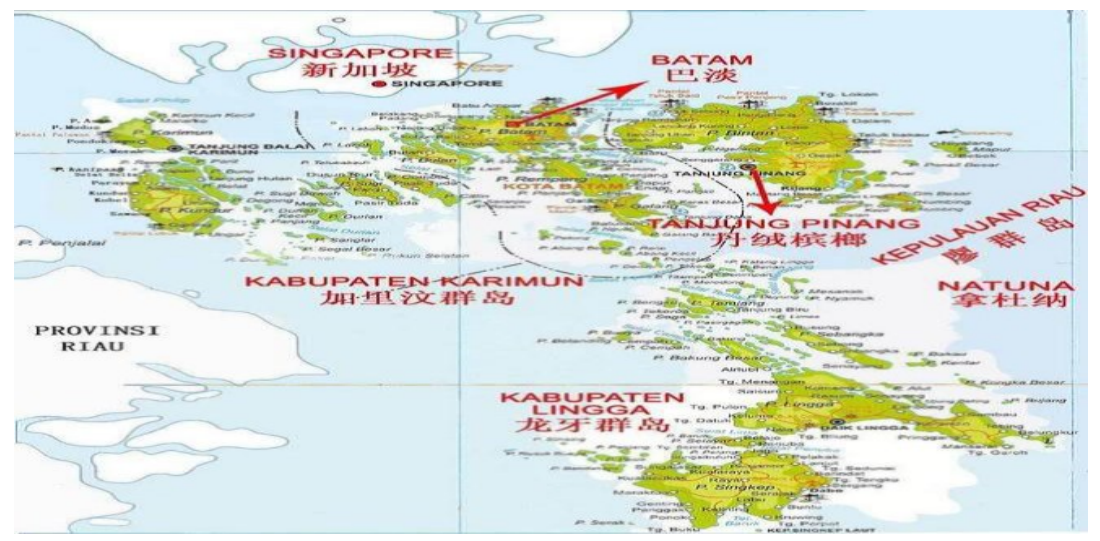

Fig. 1. Maps of Riau Islands

Source: http://www.indonesiatravelling.com

Batam City does not have natural resources which is abundant, hence economic activities the majority of the city depends on secondary sector and tertiary. This is reflected in the economic growth target the government of Batam that is driven by growth in the industrial sector and tourism. Batam who is regarded as the tropics, with 
an average temperature range from 24 up to 35 degrees centigrade (77 to 95 degrees Fahrenheit). Moisture in this area range from $73 \%$ to 96 percent. In general the rainy season starts from November until April and the dry season from May to October. Mean annual rainfall about $2600 \mathrm{~mm}$ [4].

Transportation is a means of supporting mobility, where people can use the facilities in Batam public transport as taxi, buses, and motorcycles taxi. Besides transport, Batam that is also the islands regions, sea transport is one of the important transportation connected all the islands. The use of sea transportation connecting Batam with islands around and with neighboring countries as Singapore and Malaysia, make development and transport enough, as the ship ferry (ship crossing between countries).

\subsection{Ferry Boat Classification}

Ferry boat have some type and classified based on the way landing and also how loading and unloading a ship ferry [2]:

a. Based on the way landing .Landing way consisting of two kinds of:

a) Ferry boat who land directly in the sand who named LCM (Landing Craft Manual) or LST (Landing Site Tanks). Access of the ship located at the upstream and the stern as well as having capacity conveyance greater.

b) Another ferry boat that landed in a dock. A ship this requires a wharf for berthing. Access charge there are in the hull, upstream, and stern but access in the hull not common for their place on when docked in a dock. Access passengers being on the side, directly into deck side.

b. Loading and unloading based on the way. As a broad outline technology loading and fit on the ferry can vary as follows:

a) Lo / Lo (Lift on / Lift off), namely vessel with the transfer of charge in vertical synchronization;

b) Ro / Ro (Roll on / Roll off), namely vessel with the transfer of charge horizontally;

c) Suction, namely types of vessels with the charge by means of suck / pump through a pipeline, usually combined with equipment conveyor belt (conveyor belt);

d) Special, namely types of vessels who handles one kind of charge. To another ferry boat, because of the charge of people and vehicles and did not need equipment loading and unloading special, type suitable is Ro / Ro.

Included in the Ro/ Ro vessel type:

a) A short distance vessel

b) Intermediate distance vessel

c) Long distance vessel

The type of ship that sailed between Batam - Singapore and Batam - Johor are a short distance vessel called also fast ferry. This ship could called fast ferry because his speed in splitting the beach and the strait. Usually ships this type worn in the areas of waters or the sea no undulating high. So very suitable for transportation coastal streams and lakes that the waves not to strong. This type of ships much worn by a passenger ship that connects small islands. As is the case with Batam - Singapore, Batam - Malaysia, Batam Tanjung Pinang, and Batam - Riau the mainland. 


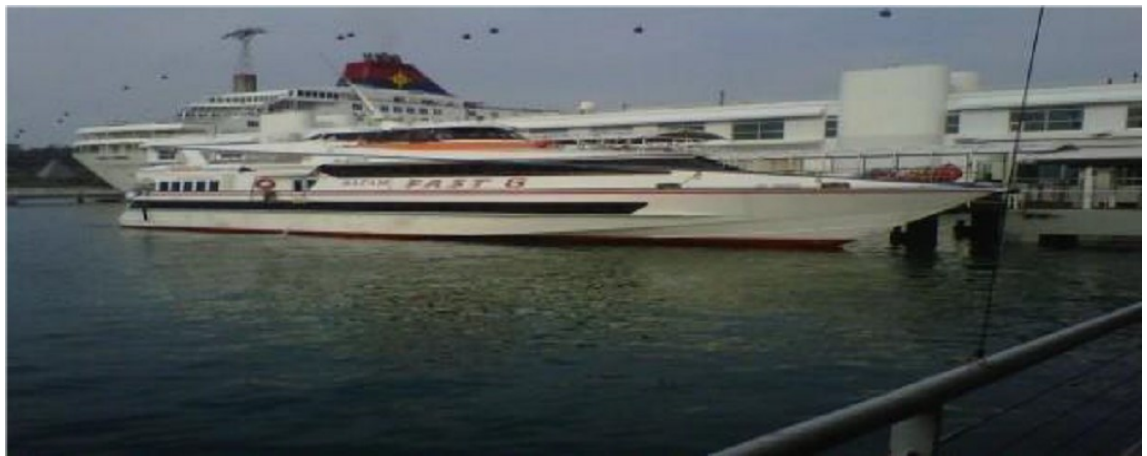

Fig. 2. Example of Fast Ferry

Source: Own Collection Data

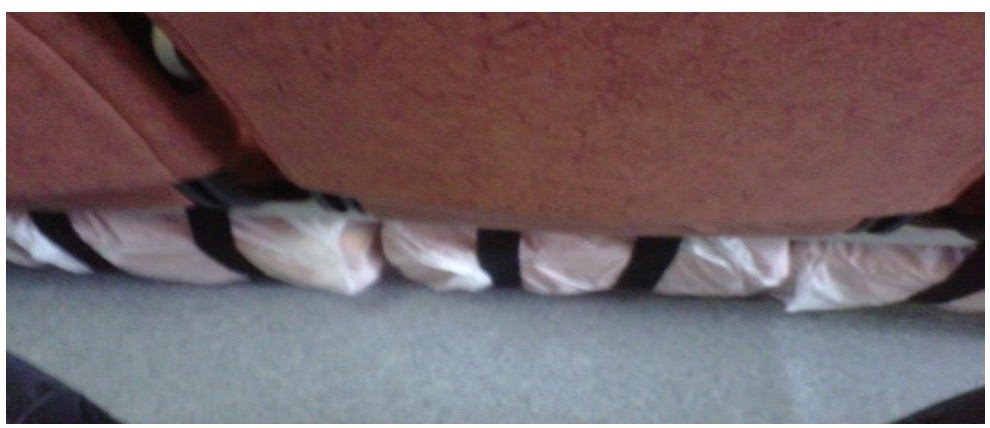

Fig. 3. Example of Life Jacket Below the Passenger Chair

Source: Own Collection Data

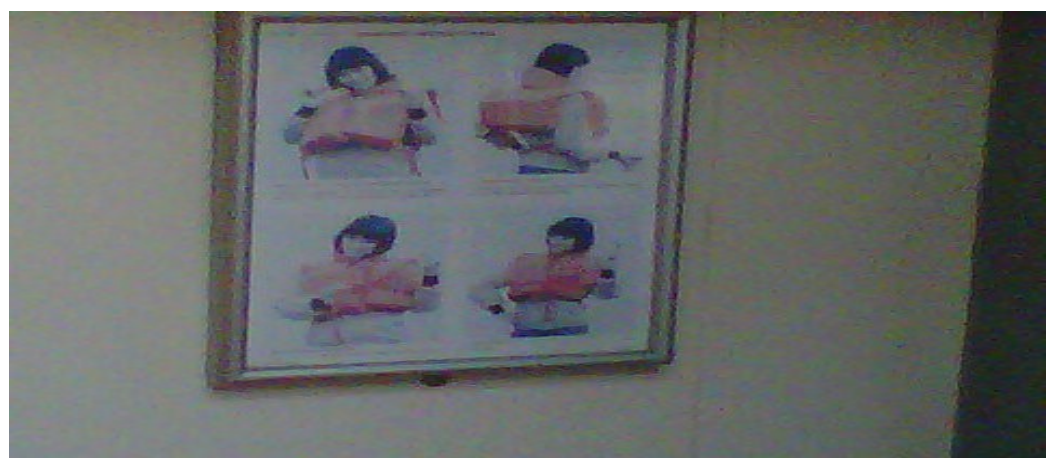

Fig. 4. A board Aids Discharging Life Jacket

Source: Own Collection Data

\subsection{Ferry Terminal Classification}

Consists of two words ferry and terminal, a point of terminal where passengers and goods in and out of the system and are essential components in the system of transport. While ferry means a vessel transportation close range [7]. Ferry terminal coordinates activities for accomodate passengers from dropping in and out of the ships at the close range or crossing boats. Also, terminal used for passenger activities from sub transit system to the sub differently characteristic of transit system. In other words means from sea transport to the land transport. Viewed from the scope of port system, ferry passenger terminal as a port component sub system serves for services inter island 
passenger ship. The ferry terminal components consisting of : 1 . The pier, is a building used for tighted ferry for loading and unloading goods and passengers. The pier depends useful of port and the depth of cruise line, namely : elongated : a dock position parallel or parellel to the shoreline especially to cruise line that is deep enough for ship motion (ship maneuvering). 2. Wharf : a dock position overhanging to sea or perpendicular coastline. It was made when the depth of port waters lacking for the ship to go in and get maneuvering. 3. Pier : between dock and coastal connected with the bridge as being a sucessors for goods movement.

\section{Result and Discussion}

\subsection{Sekupang Ferry Terminal, Batam, Indonesia}

Sekupang ferry terminal is a national and international port, located on the west coast of Batam island. It connecting Batam with the island in the west side, Tanjung Balai Karimun (the Kundur island) and Dumai (the Bird island) as well as a group of island in the south like Bangka Belitung island, and also with the city of Palembang and Jakarta. For foreign country, Sekupang port have connencting transportation line with Singapore (Harbor Front) and Malaysia (Kukup). Sekupang located in the position of 01'10'24"east longitude and 104'00'06"south latitude. Port Sekupang in its function means of the departure and arrival for visitors, should be reflected the culture for the community surrounding, expected will could integrate with society as postive thing. In addition, Sekupang port is expected to provide complete services available to the community, example for the ticket sale of service, restaurant, the higher quality product and other facilities. These services expected to get the return back for Sekupang port from service in commercial of rental place for trade, advertisement, media and parking lot. Sekupang port have facilities like ferry terminal, parking area, building facilities, including special facilities for disabled.

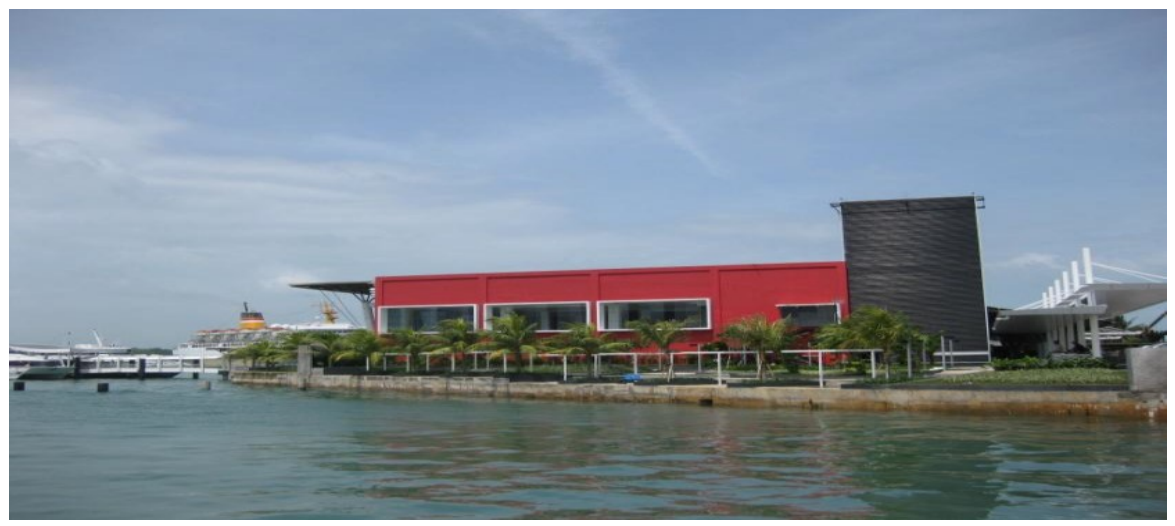

Fig. 5. Ferry Terminal Sekupang, Batam

Source: Own Collection Data

References [5] regulated about the prot. The Sekupang port consisting of 2 floor : 1 . The use of the steel structure in components column supporting areas, supporting glass area and the roof; 2 . The separated of the circulation for the passengers (for arrival and departure in the first floor with the different of entrance; 3 . Create a continuos space; 4 .Use structures wide lanscapes of space. 


\subsection{Harbor Front Ferry Terminal, Singapore}

Harbor Front is the busiest port in Singapore, because here most pasengger from Batam, Tanjung Balai Karimun, Tanjung Pinang, down from cruise and entering Singapore. It is located in front of Sentosa island, where tourism came for. There are various entertainments ranging from tourist resorts, hotel, a golf course, underwater aquarium, including Universal Studios. Harbor front also have mal that sell various trinkets, starting from the clothes, electronic, food and others, so the Harbor Front is a fused port and are in the mall.

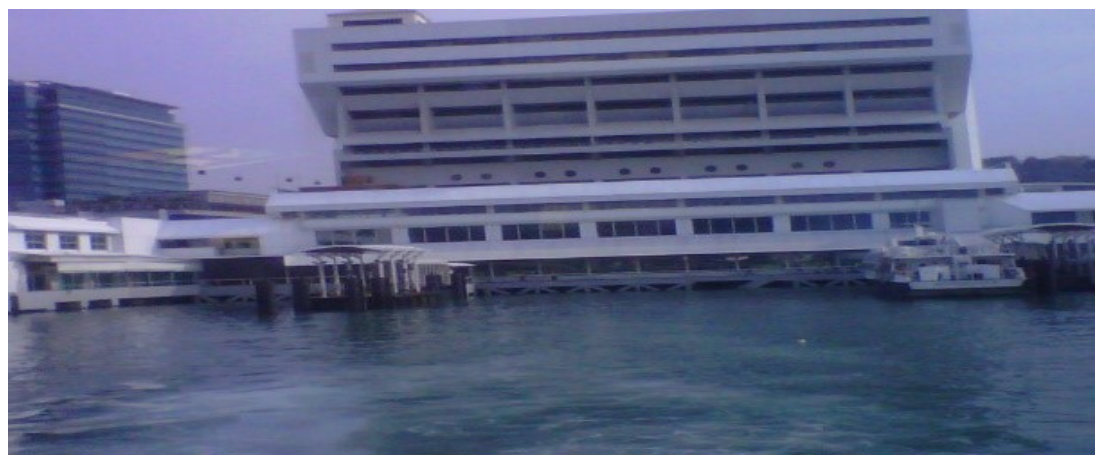

Fig. 6. Harbor Front Ferry Terminal Singapore

Source: Own Collection Data

\subsection{Batam Centre Ferry Terminal, Indonesia}

Batam Center Ferry Terminal. Batam Center is one of five international ferry terminal in Batam and the busiest terminal due to serve the route from Batam towards Singapore and Malaysia. Its location is in the center of town and the administrative center of Batam city, exactly in the way of Engku Puteri, Batam and adjacent to the hotel, the mall, and the center of Promotion of Sumatera, Batam Authority, the Mayor's Office, Immigration Office, Bank of Indonesia, Legislator Office, and other government offices in Batam. The interest of this terminal is the bridge connecting with the mall, namely Mega Mall, one of the largest malls in Batam, so tourist who come from Singapore or Malaysia can shopping there [8].

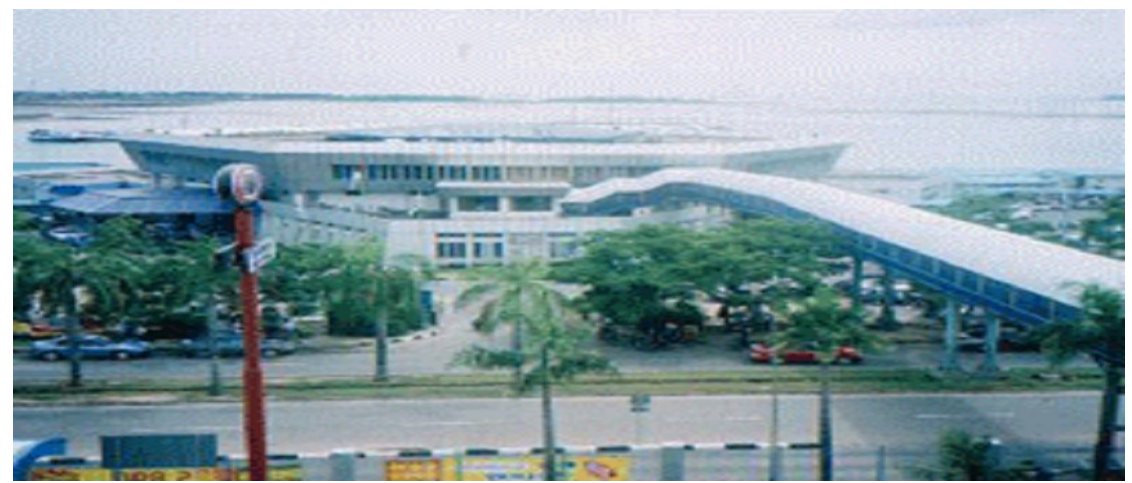

Fig. 7. The bridge in Batam Centre Ferry Terminal, Batam, Indonesia Source: Own Collection Data 


\subsection{Port of Stulang Laut, Johor Bahru, Malaysia}

Port of Stulang Laut, Johor, Malaysia is a modern harbor adjacent to the Mall is free of tax (duty free) so that tourists who want to shop for goods can buy anything with cheap price.

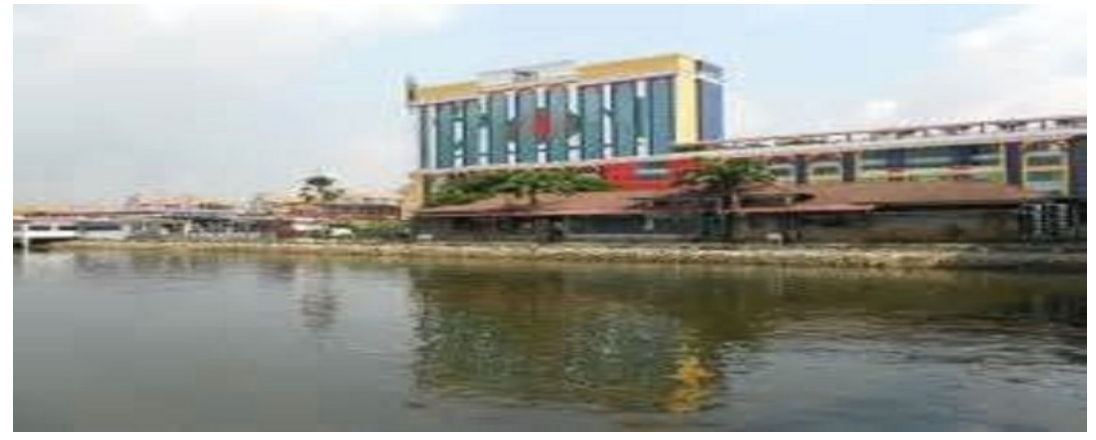

Fig. 8. Port of Stulang Laut, Johor Bahru, Malaysia

Source: Own Collection Data

There are two kinds of berthing off a ship which floats as well as four kinds of berthing others to support regular in the port of Stulang Laut. This port especially be able to accomodate until 8 ferries per hour.

\section{Conclusion}

1. For the ferries sailing from Batam to Singapore especially in Sekupang has ordered well and operating on schedule. Every port in Batam (5 ports) crossing does not cause density and mess the timetable. This because all ferries accomply with the deadline and crossing to Singapore also relative shortly only about 45 minutes once travelling.

For fast ferries sailing the route Batam to Johor, Malaysia in particular Batam Center has arranged and operated on schedule. Although there are only 2 ports serving the departure to Malaysia, Batam Center and a new Harbor Bay, but the interest of tourists to pay a visit to and from Batam always increasing.

2. Safety analysis of the ship is already fullfillment and satisfy the requirements of safety according to the Indonesian regulation. Safety facilities in a basically enough available where life jacket there is enough and put under the passenger seat that can be used when the accident, so are the raft safety outside a ship can be directly used.

3. Sekupang ferry terminal has the international terminal facilities where it has separate the departure and arrival of passengers and also have a procedure security, where on the first floor is common zone, arrival of passengers and zona management with the different entrance. On the second floor is passengers departure zone.

Batam Center ferry terminal have a decent facility as the international ferry terminal which has separated between departure and arrival passengers and also has good safety procedures as well as connected with a bridge straight to the mall, so that the tourist could be able to go shopping there. 
The Harbor Front Singapore is amodern port have fused with malls and is a place of gate to entering the Sentosa island, which region of a tourist attraction and also busiest ferry terminal in Singapore.

Port of Stulang Laut, Johor, Malaysia is a modern port adjacent to the mall and free of tax (duty free) for tourist want to shop for goods can buy anything with the cheaper price.

\section{References}

1. Batam Industrial Development Authority, "Development Progress of Batam, First Semester of 2010", Batam, 2010.

2. Faturachman, Danny, "Analysis of Indonesian Sea Border Ferry Cross Countries, Case Study: The Comparison Between Indonesia and Malaysia.(Batam - Johor and Nunukan - Tawau), MASTIC, ITS Surabaya, 2018.

3. Faturachman, Danny, "Safety Analysis of Sea Transportation in Indonesia Case Study: Crossing Between Countries in Sumatera Island (Batam - Singapore), International Journal of Advances in Mechanical \& AutomobileEngineering (IJAMAE) Vol. 3, Issue $1,2016$.

4. ICT Expo Step Forward to Batam Digital Island", Tribun Batam - Monday, 18th October 2010, accessed from http://batam.tribunnews.com

5. Indonesian Act No. 61 year of 2009 about Port.

6. Indonesian Legislation No. 17 year of 2008 about Shipping.

7. Morlok, Edward K, "Introduction Engineering and Transportation Planning", Erlangga Publisher, Jakarta, 1988.

8. Y.J. Naim, "Batam deserves to gain a high-growth economic incentives", Antara News Kepulauan Riau, 6th January 2011, taken from http://kepri.antaranews.com. 